\title{
Filipino-ness and the Heterosexual Matrix in the Work of Gregorio Brillantes
}

\author{
Wernmei Yong Ade
}

\begin{abstract}
This paper is an attempt to substantiate J. Neil M. Garcia's endorsement of Butlerian performativity in assessing what constitutes Filipino-ness, and how that Filipino-ness is constituted in post-Independence Filipino literature, focusing on two short stories by Gregorio Brillantes. Caroline Hau argues that literature is one of the structures of intelligibility through which we imagine ourselves as a nation, and ourselves as belonging to a particular nation. The Rizal Bill, passed in 1956, attested to "the existence of a disciplinary space, an ensemble of discourses and practices constituting the field of literary education over which the Philippine state sought continually to extend the scope of its nation-building projects" (Hau 1). Literature was enlisted as a means to regulate the performance of Filipino-ness; literature, as Hau's performative lexicon suggests, also performed Filipino-ness. If literature as a disciplinary practice indeed has the ability to intervene in national history, then it becomes necessary to ask, "How does literature 'represent' (in both artistic and political senses of the word) the 'true' Filipino national community? How does literature address, and resolve, the problem posed by the foreign, especially colonial 'influences' on Philippine national culture? How does literature imagine the 'foreigner' within the Filipino nation? How does literature forge the link between the personal and the political?" (Hau 9). Given its central place as a disciplinary practice in nation-imagining, what literature does has definite bearing on what Filipino-ness is. This paper answers the questions Hau raises in the context of Brillantes' short stories.
\end{abstract}

KEY WORDS: gender identity, imperialism, memory, national identity, performativity, sexuality 
Speaking at a symposium on "Knowledge, Sexuality and the NationState" in 1999, J. Neil C. Garcia asserted that

theories of gender, including if not most especially Butlerian performativity, can prove to be rather insightful as well, when used to explain an imaginary thing like "Filipino-ness"-which is to say, one's identity as nationally significative, one's selfhood as Filipino. (11)

Averring the Butlerian notion that all identity formation is performative, meaning "what one is is what one does" (7), he concluded that "national identity is a performative, [and] we might say that being a Filipino is not what one is, but what one does" (12). This article is an attempt to substantiate Garcia's endorsement of Butlerian performativity in assessing what constitutes Filipino-ness, and how that Filipino-ness is constituted in post-Independence Filipino literature. My analysis will focus on literature, particularly two short stories by Gregorio Brillantes.

I have chosen Brillantes's work for reasons I will later make apparent. I have chosen to focus on literature, because, as Caroline Hau suggests in her book Necessary Fictions, literature is one of the structures of intelligibility through which we imagine ourselves as a nation, and ourselves as belonging to a particular nation. Assessing the centrality of literature in the Philippine national consciousness, Hau's book opens with a scrutiny of the Rizal Bill, named after the Philippines' foremost nationalist writer, Jose Rizal.

At the time the bill was passed in 1956, it was part of the state's attempt to decolonize the culture of the Philippines through the use of literature, to "foster national consciousness among the Filipino people and make 'good' citizens of the Filipino youth" (Hau 1). It attested to "the existence of a disciplinary space, an ensemble of discourses and practices constituting the field of literary education over which the Philippine state sought continually to extend the scope of its nation-building projects" (Hau 1). In other words, literature was enlisted as a means to regulate the performance of Filipino-ness; literature, as Hau's use of the performative lexicon suggests, also performed Filipino-ness. Hau concludes that literature in the Philippines "came to occupy a mediating position between the 'universal' ideals of freedom and nationalism, on the one hand, and their realization within a specifically Philippine context, on the other" (2).

If literature as a disciplinary practice indeed has the ability to intervene in national history, we may then ask,

How does literature "represent" (in both artistic and political senses of the word) the "true" Filipino national community? How does literature 
address, and resolve, the problem posed by the foreign, especially colonial "influences" on Philippine national culture? How does literature imagine the "foreigner" within the Filipino nation? How does literature forge the link between the personal and the political? (Hau 9)

Given its central place as a disciplinary practice in nation-imagining, what literature does, then, has bearing on what Filipino-ness is. A large part of my reading of Brillantes's work is thus an attempt to answer these questions Hau raises.

Before proceeding further, another Butlerian tenet needs to be addressed and its relevance to the Filipino context established. The performative is regulated by what Butler refers to as the heterosexual matrix, which, Garcia explains,

determines which performances count as valid, and which performances don't. It is this matrix that stabilises the field of performativity, and lends it intelligibility. It is this matrix that constrains identity, and therefore oppresses. (8)

While admitting that the heterosexual matrix cannot be universal, Garcia insists that it does exist in the Philippines, granting that

"it's possible our own kind of matrix is organized differently from that which Butler has spelled out, even as we can anticipate it to be just as 'inescapable'-enforced, as it were, both on the level of discourse and representation, and of ritual.” (9)

Singling out Citizens Military Training (CMT) as probably being "the only monolithic homosocial masculine institution that exists in the Philippines today," Garcia recalls

how it was like to pass for "straight" while marching and saluting snappily [...] the real purpose of CMT isn't so much to instil patriotic zeal in its conscripts, as to extol a certain normative form of local masculinity, primarily at the expense of masculinity's easily identified and abjected other (which is the bakla, precisely). (13-14)

Garcia's personal anecdote demonstrates how the categories of sexuality and nation in fact interact with, constitute, and illuminate each other. In fact, patriotism, while not overtly instilled, is equated with a "certain normative form of local masculinity" (14), one based on accepting heterosexuality as a norm, even insisting on its status quo. To identify with the signifiers "nationalist" and "patriot," is to identify with the signifier "heterosexual." 
What bearing does the heterosexual matrix then have on the imagining of national identity? At which points do the discourses of nation and sexuality cross paths? How is this crossing constituted in the practice of literature, and hence the performance of Filipino-ness? In the introduction to Nationalisms and Sexualities, Parker, Russo, Sommer, and Yaeger underscore the fact that, like gender, "nationality is a relational term whose identity derives from its inherence in a system of differences" (5). Citing the work of Homi Bhabha, Eve Sedgwick, Benedict Anderson, and George Mosse, Parker et al. emphasise that there is no single or normal way for a nation to be or to define itself. In the same way that "'man' and 'woman' define themselves reciprocally (though never symmetrically), national identity is determined not on the basis of its own intrinsic properties but as a function of what it (presumably) is not" (Parker et al. 5). The reciprocal othering characterising gender relations, and hence gender identity, is now extended to include all forms of identity-race, sexuality, class, and, of course, nation.

In its early years of independence, the idea of a Philippine nation was shaped in opposition to its history of colonialism. As Cristina Pantoja Hidalgo has observed, "Philippine literature in English is inextricable from the experience of colonialism" (2). Nation, gender, and sexuality are, however, not merely analogous in the way each is constituted reciprocally with its other; these categories in fact share a constitutive relationship with each other. Sedgwick cautions us against adopting the trope of the Other in understanding something as complex as nationalism:

My sense is that an underlying liberal understanding of nationalism as an ideology, as something against which there exist conceptual tools to fight, is currently shaping our sense of the relations between nationalism and sexuality in circumscriptive ways. It's characteristic of mainstream-left thought (when it is not in the grip of utopian misunderstandings of foreign nationalisms, whose unmasking as "ordinary" nationalisms always performs another extension of the same cynical narrative) to associate nationalism in the first place and definitionally with a nineteenth-century reactionary European project of bourgeois boundary-consolidation: with rightist projects of racial, gender, sexual and other scapegoating around borders shaped by a quasi-familial ideal of purity, that would at the same time distance and justify the inflictions of overseas empire. The topos of the creation, reification, and expulsion of the Other, and signally the Orientalised other, in the emergence of the modern European state, has become a central tool of liberal analysis; and it is the explanatory aegis of the Other or Othered that has, for the most part, allowed people of variant sexualities, along with non-Christian, non-white, and 
medically-disadvantaged people, to become visible in liberal narratives about the origins of nationalism.... the trope of the Other in relation to nationalism must almost a priori fail to do justice to the complex activity, creativity, and engagement of those whom it figures simply as relegated objects-their activity, creativity, and engagement with and on behalf of, among other things, that protean fabric of public discourse that does also figure their own relegation. (Sedgwick 238-39)

Sedgwick's objections expose the trope of the other as in fact being a part of a developmental law that regulated the very field (the field of the "other") it purported to describe. Rather than being aberrant offshoots of a discursive construction of national identity, deviations in sexual, racial, and even religious identities served a prescriptive role, and were embroiled in the very discourses that made it possible to figure them as "othered" in the first place.

Social historian George Lachmann Mosse and professor of colonial studies Laura Ann Stoler have both contributed greatly in demonstrating that the formation of nation-states in the twentieth century was facilitated by the construction and regulation of middle-class norms of the body and sexual behaviour. Stoler's research is particularly illuminating, in which she argues how sexual prescriptions not only "served to secure and delineate the authentic, first-class citizens of the nation-state" (Race and the Education of Desire 11), but were also "productive of racial distinctions, of clarified notions of 'whiteness' and what it meant to be truly European" (8). Stoler adds that "[t]hese discourses provided the working categories in which an imperial division of labour was clarified, legitimated, and-when under threat-restored" (8). Stoler further argues that the discourse of race, as it intersects with a discourse of sexuality, established a relationship between

visible characteristics and invisible properties, outer form and inner essence. ... Imperial discourses that divided coloniser from colonised, metropolitan observers from colonial agents, and bourgeois colonisers from their subaltern compatriots designated certain cultural competencies, sexual proclivities, psychological dispositions, and cultivated habits. (8)

According to Stoler, Europe as a whole defined itself using a language of difference that drew on images of racial purity and (hetero)sexual virtue $(10-11)$. She asserts that racisms thus gained their strategic force, not from the fixity of their essentialisms, but from the "internal malleability assigned to the changing features of racial essence" (Carnal Knowledge 144), which include aspects of gender and sexuality. 
A discourse of sexuality thus ran parallel with the discourses of Western nationalism and imperialism, which reveals that what was at stake for the nation was not just the image of ideal masculinity, but the very relation between men and women, heterosexuality itself. The construction of ideal masculinity is bound by the heterosexual matrix, created on the basis of an unexamined perspective of heterocentricity. It is thus necessary to view sexual practices more than simply as a result of what bodies do, but as constitutive of those very bodies in the first place, without which nationimagining would be inconceivable. If the discursive management of sexual practices is central to imagining identity as nationally significative, it stands to reason that any discourse claiming to scrutinise the institutions of nationalism and imperialism, must be equally critical of the discourse of sexuality central to the efficacy of these institutions.

Benedict Anderson's attempts to rethink nationalism in terms of kinship rather than ideology provide a useful starting point for examining how the discursive formation of nation is intrinsically tied to a discourse of sexuality. Anderson defines nation as an imagined political community, in which "members of even the smallest nation will never know most of their fellow-members, meet them, or even hear of them, yet in the minds of each lives the image of their communion" (6). From this communion a community is fostered, "because, regardless of the actual inequality and exploitation that may prevail in each, the nation is always conceived as a deep, horizontal comradeship" (7). Anderson emphasizes the potency of such imagining by asserting that "[u]ltimately it is this fraternity that makes it possible over the past two centuries, for so many millions of people, not so much to kill, as willingly to die for such limited imagining" (7). In light of this, Parker et al. point out that the

"deep, horizontal comradeship" spills into and out of libidinal economies in ways that are at once consistent and unpredictable. . . nearly every aspect of Anderson's account of the nation raises issues of gender and sexuality.... George Mosse and Benedict Anderson both second this view that nationalism favours a distinctly homosocial form of male bonding. ... Typically represented as a passionate brotherhood, the nation finds itself compelled to distinguish its "proper" homosociality from more explicitly sexualised male-male relations, a compulsion that requires the identification, isolation and containment of male homosexuality. (5-6)

Gregorio Brillantes's narratives do not betray the kind of homophobia evident in the identification, isolation, and containment of male homosexual behaviour that Parker et al. refer to. The two short stories I have 
chosen to analyse do, however, enact the "love of country" (Parker et al. 1) that nationalism invokes, an "eroticized nationalism ... a commerce between eros and nation" which is apparent in the appropriation of romantic heterosexual liaisons which serve as fictive frameworks. In these two narratives, love of country is realised in fraternal relationships, framed within a narrative of failed heterosexual relationships. This means that while homosociality is not extolled at the expense of its "abjected other [...] the bakla" (Garcia 14), its performance is nonetheless legitimised by the heterosexual matrix. This is seen in how failed heterosexual relations in the stories give way to homosocial identification.

Moreover, Brillantes's most prolific work was produced during the period leading up to Martial Law, considered one of the most turbulent periods in the history of the modern Philippine nation. As Hidalgo notes, Brillantes, along with Gilda Cordero-Fernando, dominated the literature of the pre-Martial Law period (18). His writing is considered to be part of what Alice Guillermo described in 1985 as a "distinctly perceptible and growing trend towards a literary production reflective of a historical and socio-political consciousness" (qtd. in Hidalgo 18) in the midst of heavy censorship during Martial Law. Brillantes's outspoken criticism against imperialism and the then-continuing state of the Philippines as a neocolony, apparent both his journalism and his fiction, offers fertile grounds for an analysis of how the construction of Filipino-ness is not a process that can be granted any sense of stability or fixity.

Writing in 1978, Brillantes asserted that imperialism continues to be "a fact of life in this neocolony" (The Cardinal's Sins 111), aided and abetted by a ruling capitalist class whose interests inform the interests of the state, and hence US imperialism in its post-colonial reincarnation. He described the Philippines as continuing to look to the US as

Mother America, benevolent bosom of democracy lavish with milk and honey, in whose ample warmth Pinoy babes in the underdeveloped woods would find relief from all their nightmares. The appeal of that seemingly maternal refuge, encouraged by Washington and its local agents, is [however] at best a dangerous illusion. (104-05)

At the center of each of the stories I analyse lies the neo-colonial Filipino subject, who encounters Filipino-ness as "a felt sense of self, a culturally conditioned or constructed subjective identity" (Butler 324). Identity formation is a process of negotiating differences, and to this end, Brillantes's characters perform identity; their selfhood is a product 
of repeated acts-specifically, as this article shall demonstrate, in acts of cultural recollection.

Acts of memory are more than private recollections, but serve as acts of "cultural recall" (Grobbel 3). According to Mieke Bal, cultural recall is "not merely something of which you happen to be a bearer but something that you actually perform, even if, in many instances, such acts are not consciously and wilfully contrived" (Bal, qtd. in Grobbel 3). Brillantes's characters are historical subjects attempting to re-member themselves, thereby re-constructing and re-constituting their "felt sense of self" through acts of remembrance. Memory in Brillantes's works is treated as "a series of 'acts' or events in the present [which] shifts traditional interpretations of memory as 'truthful' representations of the past to concerns with the 'here' and 'now' of the present" (Grobbel 3).

In other words, past and present are configured as in a dialectical relation, opening up to what Grobbel refers to as new memory spaces, that is, new acts. Memories are thus construed as a reconstruction of the past in the present, rather than a simple resurrection of the past. As such, no act of memory is merely a repetition or reproduction of the past; each act of memory is a product in, and of, the present. The way Brillantes's characters conceive of their selves and their Filipino-ness is tied inexorably to their reconstructions of the past in the present, an act informed by a dialectical relation between a knowable historical past and an uncertain future. More significantly, these acts of remembrance unfold along a heterosexual matrix, which belies the love of country underlying the discursive representation of nation-ness. What follows is my attempt to draw out these acts of remembrance and identity-production from Brillantes's two short stories, "Journey to the Edge of the Sea," and "Janis Joplin, the Revolution and the Melancholy Widow of Gabriela Silang Street."

\section{"JOURNEY TO THE EDGE OF THE SEA"}

The year is 1955, and it has been 10 years since Marcos, the story's central male protagonist, returned from serving in the military during the Japanese Occupation. He now holds an executive position in an advertising firm, ironically located on Rizal Avenue, with a substantial American clientele. The setting is one of turmoil: "He glanced at the front page as he sipped his coffee-nuclear test ban talks stalemated in Geneva; riots in East Berlin; graft, robbery, murder; a storm brewing in the Pacific, off the eastern coast of Luzon" (Brillantes, "Journey" 85). He is married with three children, though his relationship with his wife Nina is strained. 
Marcos often reminisces about the war, particularly the fraternity between himself and fellow soldiers, which he begins to perceive in nostalgic opposition to the lack of intimacy between him and Nina. His present is overlaid with recollections of the war, evident in the way he treats his current relationships, both personal and professional, in combative terms, and his memories of war often meld into his meditations on his relationship with Nina:

He was counting retreats, re-groupings, clashes with the enemy, his memory meanwhile growing dimmer into sleep, when with a shift so slight in his half-conscious mind that he did not notice it, he began to number the occasions Nina had come home late. (84)

The one event that appears to have left a lasting impression on him is the night he and some men journey to the sea to rendezvous with an ally contact. He recalls the arduous journey made by his company across the Philippine countryside, into the wilderness, over mountains as they head towards the sea, all the while facing the threat of being discovered by Japanese planes flying overhead. Marcos and the men get into a boat to go out to meet the as yet unknown contact:

Marcos discerned shadowy figures on the coming tower, and instinctively hailed them, his voice small and lost in the ocean night. There was no answering call, and fear stabbed him then, deep and sudden in the marrow of his bones; it was like nothing he had experienced before; it came from the silence, but there were other reasons, for which long afterwards he could not quite find the nearest words: a sense of doom, of some fatal, irrevocable error; this and the mystery of the black hulk that had risen from what unfathomed depths, what darkness as vast and impersonal as time; and the instant knowledge that here was his faceless, invincible enemy, and he was helpless and exposed on the ocean... (102)

The helplessness of that night later follows him into civilian life, indicated by episodes of losing control at work followed by immediate regret. Returning home one night to find Nina still out, he feels a "dull ache began to pound in his temples, and the smoke dragged harshly in his throat; but his body was alert with the taut impatience, he felt a compressed strength rising in his chest and arms, waiting" (106). The description here parallels his wartime experience: "a wilderness of mountains, the violence and the tiredness, the dark edge of the sea, the waiting on the distant shore" (103). 
His relationship with Nina is thus characterized by the same uncertainty experienced during his service, one constantly on the brink of a violent eruption. She comes to represent for him, like the sea, a dark unknown which remains inaccessible to him yet harbouring the potential to cause extreme anxiety: "while the flush of her cheeks lingered on after the evening's excitement, her expression between a secret smile and a wistfulness perhaps, dark veiled eyes that might not look into his own" (83). Even when he thinks about her, impersonality and alienation characterise the way he recreates her image in his mind: "the hoop earrings that framed her slender mestiza face, the white stem of her neck; . . that accented the tallness of her" (82; italics mine).

Nina becomes symbolic of his darkness, a total and helpless fear, and the need to control her movements betrays a desire to master this fear. Marcos makes a promise to himself to take control:

time to put an end to this business, time for her to be home nights; where could she be, he wondered, another bienvenida in San Juan, another housewarming in Ermita, to hell with all the housewarmings in the world. (104)

When she returns home from another late night, he begins to question her regarding her whereabouts and in a moment of anger, "a blind fury jerked up his arm and flung it in a back-hand slap at her face" (107).

After this incident, the distance between them increases, and he suspects Nina of having an affair. He follows her and her male companion to a supper club, where he waits outside in a taxicab:

A peaceful, detached waiting-almost as if he were expecting an old client-replaced the frenzied activity of his brain. The night had suddenly simplified itself: a matter of waiting for a certain signal, and then a course of action as simple, inevitable, and logical ... It was like the war again-the reflex movement, the abrupt tenseness, the waiting. (110)

When he finally follows them to a house, he stands outside with a gun, waiting, as he did that night at the beach, for the right moment to confront his cheating wife and her lover.

Recollections of his past return to him, and again nostalgia for the past is fuelled by failure of his marriage in the present. Nina the unfaithful wife, his "last enemy," is juxtaposed against his "loyal men" (113). In his mind, the one (loyalty between fellow soldiers and fraternal feeling), and the other (betrayal and his failed marriage) come to stand in opposition. 
This story substantiates, quite literally, Anderson's claims that nation is an imagined community made possible by a "deep horizontal comradeship" (Anderson 7), a fraternity of men willing to die for this community:

Marcos remembered the submarine suddenly, the thrill of terror that pierced his being after he had called out, and there was no answering voice, only the such and swell of the waves against the black shape in the vast unknowable darkness. He thought of the Colonel and Narding and his loyal men ... He cleared his mind of image and emotion, tightening his grip on his gun, and stepped out of the shadows to face the last enemy. (Brillantes, "Journey" 113)

The narrative is, however, deliberately vague about who this "last enemy" is; more than Nina and her foreign lover, Marcos's final confrontation with the enemy is also with his enemy within. The narrative provides good reason to think that his confrontation with the "last enemy" (without) is a sublimated expression for what might be growing guilt (within) for perpetuating the nation's status as a neo-colony. His high powered position in the advertising firm, which entails him working overtime, is also a contributing factor towards the rift between himself and Nina.

By the end of the narrative, multiple threads of past and present identity have converged: first, his past as a soldier fighting for the independence of the Philippines from the Japanese; second, his present as an executive in a multi-national corporation that deals with a large portfolio of American clients; third, his past of belonging to a fraternity of men at war with a common foreign enemy; and fourth, his present as a lonely man at war with his "last enemy." We can see how the past and present converge here in a variety of ways that speak not only to his personal identity as a man in a failed marriage, but also his identity as a Filipino stakeholder in the neo-colonial capitalist system that currently runs the nation.

Marcos's internal conflict is palpable when we place him next to his former comrade Narding's chosen simple life as a farmer, a clear foil to Marcos's corporate job. Marcos is even envious as he thinks of Narding returning home to his wife, the image of homeliness evoked by Narding's life a contrast to the unhomeliness and (in the Freudian sense of the unheimlich) the uncanniness of his own personal life. The uncanny that seems to characterize Marcos's life is discernible in the alienation and detachment Marcos feels in his own home, and in his relationship with Nina, as well as the alienation he feels within himself as a neo-colonial subject, who at one time had fought for his nation's independence. 
Interestingly, his imagined state of Narding "spending quiet nights in the home town, reading Wolfe and Steinbeck and the new novelists, and his wife Mary knitting beside him, in the old house that faced the plaza" (Brillantes, "Journey" 103), invokes the same nostalgia for the past (the word "old" is repeated four times), which he once again places in opposition to the present. In Marcos's mind, fraternal identification (here nostalgically imagined as a longed-for innocent and incorruptible past) is seen to be reliable and stable, in contrast to the deceit that informs his marriage, and, on a larger scale, the state of the Philippines as a neo-colony. Brillantes invokes here the heterosexual matrix as that which grounds the possibility of a fraternity, by juxtaposing the failed heterosexual marriage with Marcos's longed-for fraternal feeling. Marcos's guilt, compounded with jealousy, finds sublimated expression in an act of seeming patriotism, that is, in the murder of his "last enemy."

Marcos's final confrontation with the "last enemy" and the various psychological displacements effected here elicit Bal's notion of memory as "cultural recall," as "not merely something of which you happen to be a bearer but something that you actually perform, even if, such acts are not consciously and wilfully contrived" (Bal, qtd. in Grobbel 3).

"Journey to the Edge of the Sea" thus culminates in a final act of patriotism, a sublimated "love for country" based on the notion of a loyal fraternal fellowship, as well as a desired past free from colonisation and corruption. Recalling Garcia's personal experience of CMT, Marcos's patriotic actions do indeed "extol a certain normative form of local masculinity" (Garcia 14) as his actions, carried out with a sense of duty, can be read as a recuperation of his (and the nation's) ideal of respectable hetero-masculinity, alongside "proper" homosociality (Parker et al. 6) in the form of a passionate brotherhood and a love for country.

\section{"JANIS JOPLIN, THE REVOLUTION AND THE MELANCHOLY WIDOW OF GABRIELA SILANG STREET"}

Set in the Philippines of the late 1960 and early 1970s, "Janis Joplin, the Revolution and the Melancholy Widow of Gabriela Silang Street" traces the trauma of a nation undergoing rapid change, through the relationship of its male protagonist, Crisostomo "Cris" Hidalgo, with two women, Lualhati "Lu" Layug and Elizabeth Magsarili.

$\mathrm{Lu}$ is an idealist whose communist convictions and anti-imperialist credo prove ultimately useless in the face of rapid globalization, and she is killed by a bomb during a demonstration outside the American Embassy. 
Elizabeth, in contrast, belongs to the elite capitalist class, who finally leaves the country to migrate to the US during this period of great uncertainty. Caught between these two women from opposing ends of the political spectrum is the undecided Cris, a journalist who is "quite simply more interested in people than in dogmas or ideologies" (Brillantes, "Janis Joplin" 192) and prefers writing about people than about the nation's state of crisis. Cris is the embodiment of nation-his choices reflect those of the nation, and his fate at the end of the story reflects the Philippine nation's fate.

The story begins with events leading up to the imposition of martial law by President Ferdinand Marcos (re-elected in 1969) and ends with his New Society (Bagong Lipunan) firmly in place. By the end of the story, Elizabeth's parting hope that Cris will one day find his own country is ironically realised as Cris settles in quite comfortably in the New Society. The apparent ideological restraint of "Janis Joplin" might be attributed to the conditions of Martial Law under which the story was composed. Here, the butt of Brillantes's satire is, surprisingly, grassroots nationalism and its categorically anti-imperialist stance (or perhaps not surprising given the conditions of Martial Law), embodied in the caricaturized Lu.

In her feminist critique of Brillantes's story, Sylvia Mendez Ventura argues that Brillantes's female characters are little more than representations of the "Filipino woman-warrior mystique" (80) and therefore sexist. She also notes that the viewpoint in the story is

ramified by three layers: first, the author's; second, the viewpoint of the narrator-historian who writes in the first person plural ("What of those years do we remember now?"); third, Crisostomo Hidalgo's point of view, he being the central intelligence who throws light on Lualhati Layug and Elizabeth Magsarili. A character dissection of the two women requires cutting through these three male layers. (81)

What Ventura does not expressly conclude, which a reading with Butler's performative in mind can help expose, is that the story depends on the heterosexual matrix for the development of its narrative about Filipino-ness; the story of Cris's identity formation as a historical subject caught between political worlds unfolds along his relationship with two women. While Ventura's criticism of Brillantes's caricature of Lu as the dogmatic teacher of the revolution is justified, his portrayal of Lu does however carry a serious message regarding the mere borrowing of Western ideals. The anti-imperialist lesson Lu imparts to Cris takes place in the ironically named Jefferson Lodge. Lu is the dogmatic idealistic revolutionary, who speaks in the imported tongue of communism, of "Marxism- 
Leninism-Mao Tsetung Thought" (Brillantes, "Janis Joplin" 199). Her spiel overflows with familiar left-wing jargon, borrowed clichés and textbook phrases. For being mere puppetry, Lu's revolution necessarily fails. Her death outside the U.S. embassy during a demonstration can be read as a logical conclusion of her false consciousness.

Intertextually, one might even read Cris's post-coital political education as a watered down parody of the Frenchman Marquis de Sade's infamous socio-political drama Philosophy In the Bedroom, though not nearly as risqué. In fact, Efren Noblefranca Padilla reminds us in The New Filipino Story that the ilustrados (literally meaning the enlightened ones) of the $19^{\text {th }}$ century, the earliest Filipino thinkers of revolution, were men who studied in Europe, and were largely influenced by the philosophical ideas that dominated the intellectual movement of pre-Revolutionary France. However, as Padilla further notes, "far from undertaking the enlightenment's overhaul of society and the human condition, the ilustrados held fast to scholastic philosophizing" (viii). Bearing Padilla's observations in mind, Brillantes's parodic treatment of Lu's revolutionary philosophizing might be read as a critique of the origins of Filipino revolutionary thinking, a mere borrowing of Western ideals that failed to transpire into any form of praxis.

Juxtaposed against Lu's communistic bombast is Elizabeth's laissezfaire attitude. In the scene set in her bungalow, the American presence and its cultural lingo loom large, literally in the character of the Texan Wilson Krapenberger, with his "large jowly face creased with that loud, ingenuous laughter" (Brillantes, "Janis Joplin" 208). His sheer bulk leaves an indentation in the sofa, into which Cris later sinks, foreshadowing Cris's eventual assimilation into the New Society at the end of the story. Like Lu's death, Cris's (and the nation's) destiny seems, even at this point, a foregone conclusion.

This is further suggested by Brillantes's ironic use of place. Elizabeth's massive bungalow is located on Gabriela Silang Street, named after the first Filipino woman to lead a revolt during the Spanish colonization of the Philippines, who was executed and died a national heroine. In contrast to Gabriela Silang, Elizabeth is figured here as someone who has "abandon[ed] ship" (212), who nonetheless, like Lu and Gabriela Silang, appears equally destined for death. This is strongly suggested in her identification with the 1960's American musical icon, Janis Joplin (1943-70) who at the time had just died from an overdose of barbiturates.

Elizabeth's identification with the loneliness and the "feeling" of Joplin's music is also a personal one: "She's twenty-nine. My age" (213). Joplin was also an iconic symbol of the U.S. counterculture movement 
of the 1960's, which opposed U.S. military intervention in Vietnam. Appropriated in the context of Brillantes's story, Joplin's death can be read symbolically to refer to the failure of revolution. The suggestion that Elizabeth, who wishes to escape to America, identifies with Joplin, and seems destined to share her tragic death, also indicates the failure of any possibility of escape, a stark implication that the future of the Philippinesand its people-is anything but hopeful.

Between these two polarised extremes of the political spectrum, Cris's body serves as a symbol of the nation, a site of tension between two opposing forces. However, Brillantes subverts the heterosexual masculine ideal that informed $19^{\text {th }}$ century European nationalist discourse, presenting instead a less-than-ideal, feminised male body. In doing so, he achieves two things. First, the weak male body, which hews to $19^{\text {th }}$ century colonial stereotypes of the male Filipino as weak and lazy, is a reminder both of the Philippine's colonial past, as well as its continued present state as a neo-colony. Second, the subversion of the ideal male body into a weak feminised body, further illustrates how an imperialism that "speaks in kindly or convivial tones" (Brillantes, The Cardinal's Sins 107), has managed to effectively reduce the nation to the states of apathy, complacency and indifference that now characterise it. Cris's body serves as a critique of the apathetic citizenry who believe that imperialism "doesn't really exist, [...] At best, an idea, an abstraction to be amused by; at worse, an imagined evil which drives misguided youth to smash windows" (110).

In Brillantes's subversive narrative of nation imagining, Cris's body is thus nothing like the ideal male of nineteenth century European nationalism, modelled after the stereotype of Greek beauty, invoking harmony, proportion, vigour and energy. If, as Ventura argues, Brillantes's caricature of Lu is disparaging, then his portrayal of Cris's apathy is equally so. His weakness is juxtaposed against the voluptuously full and generous body of Lu.

The contrast between the two bodies is made apparent during their tryst at the Jefferson Lodge, where Lu is described as wearing only a towel around her waist while conducting Cris's political education, her exposed twin breasts, "pink-eyed," bearing down accusingly at him like two sentinels of the national democratic forces. While she attempts to correct Cris's callous attitude towards the nation's current state of crisis, his focus is entirely on her half-naked body, his sexual reverie interrupted occasionally by concerns of eating, drinking, and smoking. His "common-place navel," "bony chest," and "thin hairy legs" (Brillantes "Janis Joplin" 199, 202) are juxtaposed against Lu's well-proportioned body, sturdy back, and 
warm substantial thigh. Her restless and impatient pacing throughout the room contrasts with his lethargy and intellectual indifference.

The juxtaposition between the two certainly inverts the ideal stereotypes. Nation, embodied in Cris, is impoverished, lacklustre and purposeless; while ideology, embodied in Lu, is wilful and full of possibilities, both politically and sexually.

While I agree with Ventura's reading that Brillantes's sexualised caricature of Lu underscores "the masculine viewpoint of the 1970s, in and out of the underground" (86), she seems to have ignored Brillantes's similar representation of Cris, which though uncomplimentary, is no less objectifying. Feminist critics of the gaze would of course argue that the female body, by virtue of the inherently phallocentric system of representation currently available, is always already an image for erotic contemplation, in a way that a male body will never accede to. This line of criticism is however limited to simply analyzing symbols of power (the image of the body, female or male), while the politics of sex remain largely ignored. By this I mean that we need to begin seeing the discourse of sexuality as it intersects with colonial discourse as more than a "graphic substantiation of who was, so to speak, on the top" (Stoler, "Making Empire" 636), that is, more than just a metaphor for domination that can be destabilized by merely subverting its terms. It is the very basis of the metaphor, the heterosexual relation itself, and how it is appropriated in post-colonial discourse, which needs to be examined.

In other words, any post-colonial appropriation of sexuality, with the aim of dismantling regimes of power, cannot afford an analytic slippage between what Stoler refers to as symbols of sexual power on the one hand, and the politics of sex, on the other. What then, does the narrative reveal about the politics of sex, that is, the intersections between colonial discourse and a discourse of sexuality? By extension, how do these intersections bear upon a post-colonial re-imagining of nation which appropriates these very discourses?

Brillantes's narrative clearly recognizes, and even acquiesces to the heterosexual matrix as that which regulates the field of performativity. Cris's uncertainty about his felt sense of self as a Filipino is explicitly displayed through his sexual relationship with a woman-two women, as a matter of fact. And while the later episode involving Elizabeth is not sexual, the text does inform us that they used to be lovers, and Cris's sexual jealousy of Walter Krapenberger is not lost on the reader.

Let us briefly return to Ventura once more, this time focusing on her observation regarding the three layers of male viewpoints that frame the 
narrative. I am interested specifically in the second layer, that of the narrator-historian who writes in the first person plural (the collective cultural "we"). Ventura reads the narrator as "Gregorio Brillantes in self-censored disguise" (82) whose account of Cris's relationship with Lu and Elizabeth in fact disguises the theme of the trauma of a nation in rapid transition.

In other words, the Cris-Lu-Elizabeth narrative is a thread running through collective cultural memory (of "we"), being the story of one man's conflict, but also that of a citizenry's conflict. We are confronted with a narrator-historian whose fictive framework purports to be an objective report on recent social history, and whose horizontal identification with the weak Cris also marks him out as equally apathetic and indifferent. The narrator in fact recognizes his own apathy as misplaced, and yet does little to try to remedy it: "The times, surely, called for a larger, a more profound and moving response than a fretful grief over the loss of a few molars which were, to begin with, rotten beyond remedy" (Brillantes, "Janis Joplin" 234). The horizontal bond between the narrator-historian and Cris exemplifies Anderson's claims once more, that nation is founded on preferred homosocial identification, here being privileged above heterosexual relations, evidenced in the deaths of the women in Cris's narrative. Cris's failed relationships with the two women become the allegorical framework, or the grounds of performance, for the narrator-historian's narrative of nation imagining. As in the previous story, failed heterosexual relationships give way to homosocial identification.

While Butler's work has been seminal in denaturalising categories of identity, it is to the work of Monique Wittig that I turn to bring my analysis of Brillantes's narrative to a conclusion. Taking the denaturalisation argument a step beyond gender identity, Wittig argues that the very category of sex itself, of "man" and "woman," is a political category. The category of sex is a product of a heterosexual relation, for, she contends, there are no men without women, meaning there is no sexual difference outside of the heterosexual relation (11). In other words, sexual difference, assumed to be a natural division, is in fact a social difference, instituted on the basis of a heterosexual relation. More than being different, men and women are categories of opposition that belong to an economic, political, and ideological order. Wittig further contends that by simply assuming that there is a natural division between men and women, rather than viewing this division as politically motivated, we in fact

naturalize history, we assume that "men" and "women" have always existed and will always exist. Not only do we naturalize history, but 
also consequently we naturalize the social phenomena which expresses our oppression, making change impossible. (11)

Appropriating without question the natural relation between man and woman towards a post-colonial discourse unwittingly invokes what Brackette Williams refers to as a nationalism that rests on a myth of origins, producing "'nations' of the old school (i.e. biologically 'pure' peoples), sharing 'self-produced' cultural patrimony [who] are intent on the realisation of a "racial' destiny befitting their presumed biogenetic heritage" (2).

The two stories analyzed here expose the heterosexual matrix, that which stabilizes the field of performativity, to be that which also lends intelligibility to what constitutes Filipino-ness. Brillantes appears to have been aware not merely of the interconnectedness between nation and sexuality, but more importantly, of the heterosexual matrix that constrains identity formation. Without however rejecting the heterosexual matrixone can hardly have expected him to, writing in the 1970s and 1980sBrillantes exposes sexuality as a regulating fiction intimately connected to performing national identity. This is largely effected by his brilliant use of irony: while his male protagonists are seen to be in control, the ones who appear to come out on top, Brillantes maintains an ironic, critical distance from them. His subtle mockery of his male protagonists ${ }^{1}$ means that the reader is never allowed to fully trust the assumptions held by his male protagonists or narrators, their decisions or motivations to act. Consequently then, whatever views his male protagonists or narrators hold which might be construed as sexist, should be taken with slight skepticism.

What Brillantes does make clear is that, just as there is no such thing as a stable, true gender identity, there is no such thing as a definite sense of what Filipino-ness is, which simply finds expression in everyday living. Rather, like gender identity, Filipino-ness involves a constant, and often conflicting process of negotiating between self, other, past, present, as well as with the regulatory fictions that lend such doing their intelligibility.

${ }^{1}$ For instance, his other story in this collection, "The Fires of the Sun, The Crystalline Sky, The Dark Ocean, and Some Women and/or girls, including Napoleon Espiritu's First Granddaughter," draws on Nabokov's paedophile and self-professed poet Humbert Humbert for its characterisation of the aging Espiritu who falls in love with a seventeen year old girl. 
Asian Perspectives in the Arts and Humanities 3.1 (2013): 79-98

\section{WORKS CITED}

Anderson, Benedict. Imagined Communities: Reflections on the Origin and Spread of Nationalism. $3^{\text {rd }}$ ed. London: Verso, 2006. Print.

Brillantes, Gregorio. "Janis Joplin, the Revolution and the Melancholy Widow of Gabriela Silang Street." The Apollo Centennial. Manila: National Book Store, 1980. 81-113. Print.

---. "Journey to the Edge of the Sea." The Apollo Centennial 188-220.

--- The Cardinal's Sins, the General's Cross, the Martyr's Testimony and Other Affirmations. Manila: Ateneo de Manila UP, 2005. Print.

Butler, Judith. "Gender Trouble, Feminist Theory, and Psychoanalytic Discourse." Feminism/Postmodernism (Thinking Feminism). Ed. Linda J. Nicholson. New York: Routledge, 1990. 320-46. Print.

Hau, Caroline S. Necessary Fictions: Philippine Literature and the Nation, 1946-1980. Manila: Ateneo de Manila UP, 2000. Print.

Garcia, J. Neil C. "Knowledge, Sexuality and the Nation-State." Performing the Self: Occasional Prose. Quezon City: U of the Philippines P, 2003. 3-15. Print.

Grobbel, Michaela M. Enacting Past and Present: The Memory Theaters of Djuna Barnes, Ingeborg Bachmann, and Marguerite Duras. Lanham, MD: Lexington, 2009. Print.

Hidalgo, Cristina Pantoja. Fabulists and Chroniclers. Quezon City: U of the Philippines P, 2008. Print.

Padilla, Efren Noblefranca. The New Filipino Story. Iowa: Kendall/Hunt, 1998. Print.

Parker, Andrew, Mary Russo, Doris Sommer, and Patricia Yaeger, eds. Nationalisms and Sexualities. New York: Routledge, 1992. Print.

Parker, Andrew, Mary Russo, Doris Sommer, and Patricia Yaeger. "Introduction." Parker et al. 1-20.

Sedgwick, Eve Kosofsky. "Nationalisms and Sexualities in the Age of Wilde." Parker et al. 235-45.

Stoler, Ann Laura. Carnal Knowledge and Imperial Power: Race and the Intimate in Colonial Rule. Berkeley, CA: U of California P, 2002. Print.

---. "Making Empire Respectable: The Politics of Race and Sexual Morality in 20 th Century Colonial Cultures.” American Ethnologist. 16.4 (1989): 634-60. Print.

---. Race and the Education of Desire: Foucault's History of Sexuality and the Colonial Order of Things. Durham, NC: Duke UP, 1995. Print.

Ventura, Sylvia Mendez. Feminist Readings of Philippine Fiction: Critique and Anthology. Quezon City: U of the Philippines P, 1994. Print.

Williams, Brackette F. "Mannish Women and Gender After the Act." Women Out of Place: The Gender of Agency and the Race of Nationality. Ed. Brackette F. Williams. New York: Routledge, 1996. 1-36. Print.

Wittig, Monique. The Straight Mind and Other Essays. London: Harvester, 1992. Print. 
Wernmei Yong Ade is an Assistant Professor with the Division of English at Nanyang Technological University (Singapore). She received her PhD from the University of Edinburgh in 2006. Her thesis centered on the subject of communication in the philosophical writings of Georges Bataille and the fiction of Angela Carter. Her current research focuses on the subject of love as a discourse of alterity in the works of several contemporary women writers, and covers the novels of Angela Carter, Toni Morrison, Anita Desai, and Jessica Hagedorn. Her most recent publications include "Obscenity, Ruin and the Metaphor of the Eye" (in On Reading: A Collection of Essays, Atropos Press, 2012), "The Sacred: Of Violence, Intimacy and Love" (Special issue of Philosophy Today, Summer 2012), and "Writing Woman, Reading Woman: Re-vision in the poetry of Lee Tzu Pheng" (SARE, no. 50 - Singapore and Malaysia Special Issue, 2012). She is currently working on an edited collection of essays tentatively entitled Embodying Singapore: Critical Perspectives on the Arts, Society and Politics. 